\title{
Cores of Poverty in Slovakia
}

Abstract The study deals with spatial differentiation of poverty and identification of poverty centres in Slovakia.. Method of multiple deprivation was used in identification of poverty centres; 419 poor municipalities were identified in Slovakia. Poverty in these municipalities is connected with many historical, natural, political, economic and social phenomena and processes and possesses many common features. The study also contains analysis of principal features of poverty which indicated the population groups most struck by poverty. Generally, poverty of rural population prevails, it strikes children and from the point of view of ethnic composition it is most distinct in the Roma minority and affects unemployed or those employed in the primary sector. Cognition of the local/spatial dimension and character (features) of poverty determined the generation of regional and local programmes of poverty elimination.

Key words poverty indicators, level of poverty, multiple deprivation, poverty centres, features of poverty
* RNDr. Anton Michálek, CSc, Institute of Geography, Slovak Academy of Sciences (SAV), Štefánikova 49, 81473 Bratislava, Slovak Republic

geogami@savba.sk

\section{Introduction}

One of the greatest global problems is poverty which in turn is the cause of other global problems such as malnutrition, infectious diseases, illiteracy, etc. Poverty interpreted in this absolute sense of the word is characteristic for the countries of the third world where great parts of populations struggle to survive. But it is not only the problem of the developing countries, it also affects industrialised countries (for instance in the USA there live 30 million people below the officially established limit of poverty). Poverty also became distinct in the transiting countries of eastern and central Europe in the 1990s in the consequence of socio-economic changes which exposed until then disguised low living standard of part of population on the one side, and brought about some new phenomena which cause poverty (unemployment, increase of economic, social and income inequalities) on the other. Slovakia is also the country where distinct differences are observable in spatial distribution of poverty. There are rich regions situated in western and north-western parts and explicitly poor regions situated in southern and eastern parts of the country. Pronounced differences in the economic level of regions affect and increase the income inequalities of population which cause an important concentration of poverty in certain localities.

\section{Geography of Poverty}

Poverty as manifestation of certain state of the society, households or individual in its spatial form is one of important themes of the world human geography. Comparatively extensive and thematically varied literature on concentrates now on: uneven development of the origin and deepening of deprivation areas, distribution of new poverty subcultures, poverty cycles, inequalities, deprivations, shift and propagation of poverty into neighbourhood, delimitation within the city, "positive" discrimination, etc. Knowledge of spatial dimension of housing segregation of poor people, information about income and overall situation of economically active and unemployed persons, about differentiation on regional labour markets, formation of subgroups and their spatial distribution, about causes and conditions of exclusion of the poor, about the effects of geographic, social and economic dimensions and other key territorial elements, are constantly gained. The amount of knowledge concerning improvement of programmes and strategies preventing and limiting poverty also increases. The themes involved in the extent or level ${ }^{1}$ of poverty in the world countries and regions are most frequently treated and represented.

\section{Aims of the Study}

As poverty in Slovakia is one of the most serious problems (it is especially acute in some regions and settlements), this is an attempt to identity the poorest settlements (municipalities) and regions. In such localities apart from relative poverty (in the sense of exclusion of the struck population out of the living standard common in the society) there is also part of population (homeless people, the Romas living in Roma settlements) living in absolute poverty struggling for survival every day. Determining of the poverty rate in settlements with different size is especially important in case of Slovakia, as the country is characterised by deep regional differences. Knowledge of poverty in Slovakia, above all at the local level, is the basic prerequisite and salient point for search of solutions and control programmes. This study is in fact the effort to capture and measure the poverty rate in the municipalities of Slovakia as of the most recent population census (2001). The aim of the study is to analyse spatial differentiation of poverty at a local scale, to measure its level in every municipality of Slovakia followed by identification of municipalities(regions) with the severest level of poverty. As poverty is characterised by different attributes, the study also contains the attempt to outline its nature and features in Slovakia. Observation of spatial aspects and features of poverty and identification of its cores in Slovakia is, apart from its cognitive aspect, the response to the social demand associated with generation of new approaches to social and regional policy, part of which is a complete information about the level and nature of poverty in the individual municipalities and regions.

\section{Conceptualisation of Poverty in Relation to Space}

The level of poverty in regions and communes can be studied by means of different concepts (direct, indirect, prescriptive, consensual, objective, etc.) which are mostly based in measurement of the share of poor population - scope of poverty, as de- 
termined by the chosen approach (Mareš, Rabušic 1996, Michálek 2000). Each of the quoted concepts of poverty measure in different territorial units possess some pros and contras, hence it was necessary to choose the concept (way of measure) which was easily applicable and interpretable and offered a relevant and true information on the poverty level in regions.

As it is not possible to measure poverty level in municipalities of Slovakia (such measurement at the local level is also rare in other countries) by means of data on income and consumption, which are used in advanced countries, it was necessary to choose such concepts which measure the poverty level by means of other available data. They are the data associated with char acteristics which determine, indicate or accompany poverty and are currently used by social and human geographers. They are approaches based on observation of other, wider scale of characteristics than the mere income and consumption. They are concepts which measure poverty more comprehensively taking into account the inequalities of social and material welfare or deprivation. One of important approaches is that of Townsend's concept of multiple deprivation $(1978,1987)$, which measures poverty by means of the multiple deprivation index. The essential trait of this approach is that it expresses deprivation in terms of consumption, possessions, living and social conditions and other living standard components through a single synthesised indicator.

\section{Concept of Multiple Deprivation}

The concept of multiple deprivation inter prets poverty as deprivation where the size of the summarised deprivation is determined by the level of deprivation of studied dimensions (characteristics) multiplied by their weight based on the effect (scope) of selected factors on poverty. Six most important characteristics about which data at the level of municipalities exist were chosen from those which cause, indicate or accompany poverty. They were indicators of unemployment, education, size and completeness of household, overcrowding of living place and lack of bathroom/shower in the living place. All quoted characteristics are often applied in similar studies as they are in a highly positive correlation with poverty.

Study of Michálek 2004 contains the criteria of choice and brief characteristics of indicators. The size of summarised deprivation along with weights of indicators eventually provides the resulting picture of the level of multiple deprivation, while those municipalities which reached the highest values of multiple deprivation are simultaneously the municipalities with the highest level of poverty (see the map). Essentially, poverty interpreted in this way is a multidimensional phenomenon which implies sev- eral aspects of personal deprivations. Some quantitative sociologists and economists even consider this procedure of poverty observation better than its identification only by means of income and consumption, as it reflects long-term economic difficulties and different forms of deprivation.

\section{Synthesised Indicator of Poverty Level in Municipalities}

The basic means of poverty assessment in municipalities of Slovakia are the abovementioned indicators. By quantifying them, the synthesised indicator was set, the value of which expresses the multiple deprivation level or poverty of a municipality. Quantification relies on assessment of deprivation level (expressed in points) and on weighing the studied dimensions. Point evaluation is done on the basis of what level of deprivation is reached by each of dimensions in the individual municipalities. In point evaluation it was necessary to assess the importance and weight of dimensions in relation to poverty. The relative mutual importance is denoted as the weight of indicator. The weight provides information on relative importance, effects or relationship to the particular problem studied, in our case, to poverty. Several methods of its determination exist in the field of decision making analysis while all of them try to transform (it is not always possible) the qualitative arrangement of importance of factors to quantitative arrangement (Ríha 1987). The ranging method was used for determination of the weight of selected indicators. It hierarchises indicators according to their relative mutual importance. The determination of the relative mutual importance (hierarchisation) of studied indicators was based in obtained values of correlation dependencies of indicators with poverty (Mikrocenzus 1997b). The higher the values of dependence, the higher the preference (range). Each indicator was assigned the order number, where number 1 corresponded to the most important and the $\mathrm{N}$ corresponded to the least important indicator. In some cases, also in our case though, some indicators can be equally important; consequently the reach the same order and then $\mathrm{N}<\mathrm{n}$. Then it is necessary to use what is referred to as a standardised order. In our case 5 values of order were assigned to six indicators as indicators 2 and 4 were relatively equally important in relation to poverty. Each indicator was assigned values from 1-5 interval, while the most important indicator with the highest rank of importance (evaluation) unemployment obtained 5 points. Eventually, the weights of the individual indicators $(\mathrm{Wj})$ were established by computing them as the share of point evaluation of indicator importance and its standardised order. Assessment of the indicator's weight ( $j$ ) is expressed as follows:
$W_{j}=w_{j} \div x_{j}^{(s)}$

$W_{j}=$ weight of indicator $j$

$\mathrm{w}_{\mathrm{j}}=$ point evaluation of indicator importance $j$

$\mathrm{x}_{\mathrm{j}}{ }^{(\mathrm{s})}=$ standardised order of indicator $j$

Determination of weight of indicator and point evaluation based on chosen scale does not represent the synthesised picture on deprivation level (poverty). It is provided by the synthesised indicator $(U)$ which is expressed as the sum of products of weight (W) by point evaluations (b) of all chosen indicators. The synthesised indicator $(U)$ is simultaneously the result (numerical expression) of poverty level evaluation in $\mathrm{mu}$ nicipalities of study region. It can be expressed as:

$$
\underset{\mathbb{Q}=1}{\mathrm{n}}=\Sigma \mathbf{W}_{\mathrm{j}} \times \mathbf{b}_{\mathrm{j}}
$$

$\mathrm{U}=$ synthesised deprivation indicator $W_{j}=$ weight of indicator $j$

\section{$b_{j}=$ point evaluation of $j$-th factor}

Sum of points by factor weight products in the lowest theoretical value represents the convenient value of Umin, the value Umax is totally inconvenient. Their value moves in our case in the interval from 11.7 to 51.0 .

\section{Poverty Level in Municipalities of Slovakia}

Evaluation of poverty level in municipalities of Slovakia shows that the reached values of the synthesised poverty indicator oscillate a wide scale; it reveals the existing great differences in poverty level in the individual municipalities - great spatial diversity.

This evaluation reveals that 419 (of 2,922 or $14.3 \%$ ) of municipalities can be considered the poorest. The poverty indicator in these municipalities exceeded the value 38 of indicator (all values higher than 38 lie in the $5^{\text {th }}$ pentil) what means that these municipalities represent the real cores of poverty in Slovakia (the highest Umax value $=51.0$ was reached by 9 municipalities).

The poorest municipalities are situated in 43 of 79 administrative districts of Slovakia. Nevertheless, only one such municipality was identified in 16 districts. More than a half of municipalities is concentrated in 9 districts; 127 municipalities or more than 30\% fall under four (Rimavska Sobota, Revuca, Velky Krtis, and Lucenec) southern districts of central Slovakia, another 77 (18.4\%) are in four (Michalovce, Trebisov, Bardejov, and Roznava) districts of eastern Slovakia and twenty in district of Levice in western Slovakia. The majority of the total number of 419 poor municipalities are situated in district of Rimavska Sobota where as much as 60 such municipalities(56.1\%) concentrate. Municipalities with the highest level of poverty in relative values are most represented in the district of Revuca amounting to $57.1 \%$. More then a third of such municipalities are in the districts 


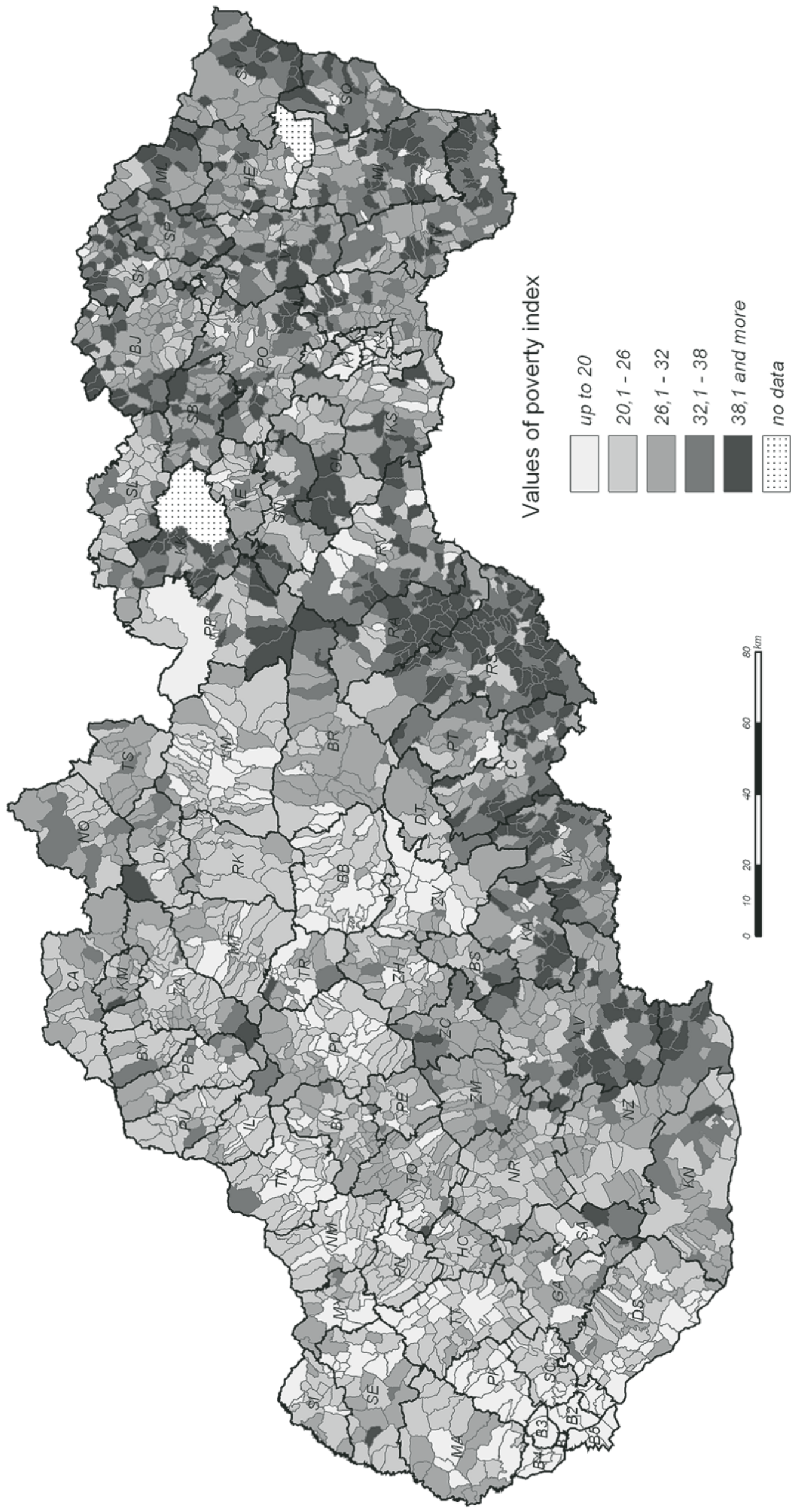

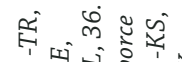

ช फิ जी

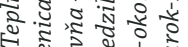

के

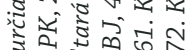

के ㅇำ के

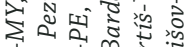

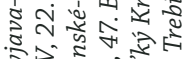

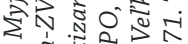

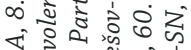

से संख्या के

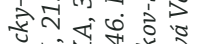

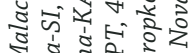

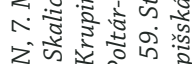

ते भे की के

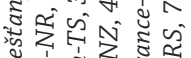

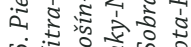

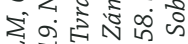

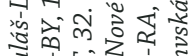

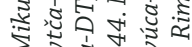

से है हों

को 0 :

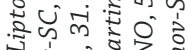

in 4 i

๓ं के भुष के के

今 $\begin{gathered}0 \\ 0\end{gathered}$

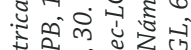

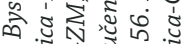

ซั้

00

म.

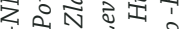

है जิ

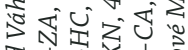

خे

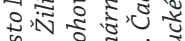

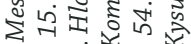

ถิ

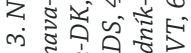

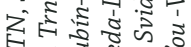

จ

के है क्षे क्षे के

ชั.

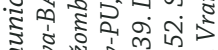

है है कै क्षे

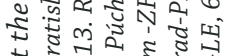

और की

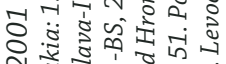

.

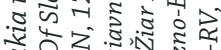

की

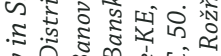

政

ठิ.

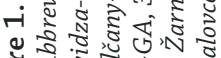

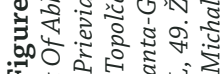

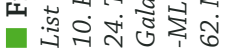


of Kezmarok and Lucenec and more then a quarter of them are in districts of Velky Krtis, Roznava, Michalovce and Vranov nad Toplou. Above quoted administrative evaluation (according to the territorial-adminis trative units at district level - NUTS 4 now in force) does not allow to follow some important aspects, for instance existence of poor regions which do not coincide with district boundaries. This is why, poor municipalities were observed from the point of view of their neighbourhood, and the result was that almost a half of them form regions of poverty in the sense of the adopted criterion ${ }^{2}$. There are 199 (47.5\%) municipalities and they form 8 important poverty regions. The largest poverty region is that of Rimavska Sobota as it contains 96 poores municipalities; 57, 23, 10, and 6 of them are in districts of Rimavska Sobota, Revuca, Roznava, and Lucenec respectively. The second largest of them consists of 23 municipalities situated in three sdistricts (Kosice-environ 8, Vranov nad Toplov 8, and Presov 7). Another district is that of Velky Krtis with 19 municipalities lying in the territory of districts Velky Krtis (13) and Lucenec (6). It is followed by three regions of poverty formed by 13 municipalities each (Snina and Sobrance 11+2, Nove Zamky and Levice 7+6, and Kezmarok 13). The region of Michalovce consists of 11 municipalities and that of Svidnik of 10 municipalities.

\section{Features of Poverty in Slovakia}

Poverty in Slovakia is characterised by several features which are different from those in other countries. A very significant and typical feature of poverty in Slovakia is its rural character. It is proved by the fact that the mean size (in terms of population) of a poor commune is only 691 inhabitants (for comparison: the mean size of municipality in Slovakia is 1,831 inhabitants).

As far as the age structure is concerned, it is possible to say that the majority of poor municipalities is characterised by a progressive type of population, which means that the child component (below 14 years) prevails (or considerably prevails in some municipalities) over the population group at the post-productive age. While the child component represents $19 \%$ in population of Slovakia as a whole (Slovakia boasts one of the youngest populations in Europe), the child component in poor municipalities represents as much as $23 \%$. This share exceeds $30 \%$ in 95 of all poor municipalities where almost direct dependence is observable which points to the fact that the municipalities with the highest representation of children are also characterised by the highest poverty index values. It means that the child poverty exists in Slovakia

Ethnic appurtenance is an important element in structure of poverty and inequality in almost all countries. Poverty more often appears among the Roma people in the consequence of their low qualifications and unreliability, which disqualify them on the saturated labour market. The more Romas live in a municipality, the higher the level of poverty. The municipalities with incorporated Roma settlements are absolutely the worst. It means that ethnic poverty exists in Slovakia.

The population of poor municipalities suffers from very adverse situation on labour market. While the share of unemployed was $25.6 \%$ of total number of economically active persons in Slovakia, this share climbed to almost a half $(47.6 \%)$ of economically active persons in poor municipalities. In 117 municipalities the number of unemployed was higher than that of employed and in 25 municipalities the unemployment rate exceeded $70 \%$. This is the new poverty related to labour market

The risk of poverty increases not only with unemployment rate. It is also influenced by the industry the persons are employed in. Part of poor population is formed by employed persons with low wages, typical for the primary sector. It was found out, that precisely in poor municipalities there is a higher rate of persons employed in this sector. While $9.8 \%$ of total population of Slovakia works in the primary sector, this rate equals $12.8 \%$ in poor municipalities. We can talk about sectoral poverty connected with economic activity of population.

All identified municipalities with the highest level of poverty are economically underdeveloped and their infrastructure and economic potentials are low. The week and insufficient economic basis of studied municipalities is also characterised by low production and poor representation of private businesses (ŠÚSR 2002). The original monofunctional economic basis of rural settlements was weakened in transition period. Adverse impact also manifested in high unemployment and simultaneously in high share of dependent population, low purchase power, social exclusion and the like (MPSVaR 2002).

\section{Conclusion}

This study presents one of possible analyses of spatial differentiation of poverty or identification of poverty cores at the level of municipalities. The obtained results provide the picture of spatial distribution and concentration of poverty in municipalities (its level expressed by poverty indicator values) and also show their position in study territory. It was found out that there is a very serious situation in 419 municipalities where the poverty indicator reached critical values. More than a half of the poorest municipalities forms continuous poverty regions (8) which lye mostly in those areas of Slovakia which were historically the poorest parts of the country. High poverty level in these regions (municipalities) is linked to many historical, natural, political, and socio-eco- nomic phenomena and processes. Poverty in Slovakia is characterised by traits which are consequences of an entire series of external, internal and individual causes.

\section{Acknowledgement}

The presented research was supported under Grant No. 3083, Scientific Grant Agency of the Ministry of Education and the Slovak Academy of Sciences (VEGA).

\section{Notes}

Poverty level is one of the basic measures of poverty. It is often confused with scope of poverty which is only possible if the poverty level is measured or expressed by the share of poor population in total population. This frequent confusion is linked to the fact that in the majority of studies poverty level is actually measured by extent of poor population. But the poverty level can be also expressed by other ways, such as through the established limit, in our case, the deprivation limit.

Continuos territory formed by a minimum of 10 municipalities with the lowest level of poverty is considered the poverty region.

\section{References}

Dahrendorf, R.: Moderný sociálny konflikt, Archa Bratislava 1991.

Jütte,R.: Poverty and Deviance in Early Modern Europe, Cambridge University Press, Cambridge 1994

Mareš,P.: Sociológie nerovnosti a chudoby, Sociologické nakladatelství, Praha 1999. Mareš,P., Rabušic,L.: K měření subjektívní chudoby v české společnosti, Sociologický časopis 32, 297-315, 1996.

Michálek,A.: Chudoba, jej koncepty a geografické dimenzie, Geografický časopis 52, 231-242, 2000.

Michálek,A.: Meranie chudoby územných celkov, Sociológia 36, 7-30, 2004.

Ministerstvo práce sociálnych vecí a rodiny SR.: Správa o sociálnej situácii obyvatelov Slovenska v r. 2001, MPSVaR SR, Bratislava, 2002.

Nolan,B., Whelan,Ch.: Measuring Poverty Using Income and Deprivation Indicators. Alternative Approaches, Journal of European Social Policy, 6, 225-240, 1996.

Pacione,M.: The Geography of Multiple Deprivation in Scotland, Applied Geography 15, 115-133, 1995.

Ríha,J.: Multikriteriální posuzovaní investičných záměru, SNTL a Alfa, Praha, 1987.

Štatistický úrad SR.: Regionálne porovnania v SR, ŠÚSR Bratislava, 2002.

Townsend,P.: Poverty in the United Kingdom: a Survey of Household Resources and Standards of Living, Penquin, Harmondsworth, 1979.

Townsend,P.: Deprivation. Journal of Social Policy 16, 125-146, 1987. 